national treaties. A legal agreement does exist between the Russian Fed. eration and Azerbaijan. It protects the citizens of each of these republics on the other's territory. There is also an agreement on interstate relations between the Russian Federation and Estonia and another on legal assistance in civil, family, and criminal cases. The latter regulates the protection of the rights of the citizens of both states in the event of property disputes. An agreement on regulating migration and protecting migrants' rights has been prepared by the parliaments of Russia and Tajikistan but has not yet been ratified. The problem of establishing and efficiently operating embassies and consular services in the republics is urgent because these institutions can give assistance and protection and offer naturalization services. Many voluntary organizations exist and are already rendering assistance. There are also national minority funds in the former republics but the help they provide is very limited. They need state support and financial assistance themselves.

We conclude that migration to Russia is largely uncontrolled and spontaneous. Russia and other states are unable to protect the rights of their citizens outside their boundaries. Given that financial and material means of assistance are so meagre, Russia can hardly deal with the stream of migrants, who must rely largely on their own devices.

\begin{tabular}{|lcc|}
\hline \multicolumn{3}{|c|}{$\begin{array}{l}\text { Table 9: Attitudes of Muscovites } \\
\text { Toward Various Ethnic Groups } \\
\text { (in percent) }\end{array}$} \\
\hline \multicolumn{3}{|c|}{ Positive } \\
Ukrainians & 67 & 3 \\
Jews & 56 & 8 \\
Tatars & 53 & 11 \\
Moldavians & 47 & 7 \\
Latvians & 47 & 7 \\
Armenians & 37 & 34 \\
Georgians & 36 & 33 \\
Gypsies & 31 & 33 \\
Chechens & 27 & 40 \\
Azeris & 26 & 46 \\
\hline
\end{tabular}

\title{
Part IV \\ Crime and the Socio-Psychological Background of Migration
}

Migration has not jeopardized the social situation everywhere in Russia. We must look at its effects in each region separately. For example, in the central part of European Russia the situation is very favourable. There is a relatively high degree of ethnic tolerance. ${ }^{16}$ The Centre for the Study of Public Opinion at Moscow State University carried out a survey of public opinion in 1992 which demonstrates this. Some 1,009 Muscovites 18 years of age and over were interviewed. Twothirds of them think that they do not have problems with members of other ethnic groups even though they live in a big multinational city. This indicates great tolerance on the part of Russians despite the growth of anti-Russian feelings and actions in many republics of the former USSR. Some respondents connect the existence of some problems with the multinational character of the Russian capital-17 percent say that the rise in crime, and 12 percent say that non-sanitary conditions, are connected to ethnic diversity. But it is recognized that these problems are of socioeconomic, not ethnic, origin. Such problems as mentioned above are characteristic of any big city. In Moscow they simply reflect the condition of the society and the insufficient work being done by the municipality. One can judge from Table 9 the attitudes of Muscovites toward non-Russian nationalities. They show that attitudes are worst toward Azeris and Chechens.

Other research shows that only a small proportion of people in the Tambov region regard ethnic principles very seriously when they choose neighbours. Moreover, only a tiny proportion of them dislike having neighbours from another ethnic group (see Table 10). ${ }^{17}$

Alongside the tolerance of the Central Russia population there are some areas in Russia where social and international conflicts caused by the streams of refugees and migrants are dangerous to the point of explosion. This is the situation in the south of Russia (the Northern Caucasus region), where 75 percent of refugees are concentrated, mainly in Krasnodar, Rostov and Stavropol regions. It has become very typical of refugees to move to the southern areas and try to settle there, but not to the central regions of Russia as has been recommended by the authorities.

The Russian-speaking migrants posses high labour potential and are not afraid of difficulties. They have broken with their previous lives and are creating their own farms and businessess in deserted and neglected areas. Reviewing research sponsored by the Scientific Centre of the Ministry of Foreign Affairs of the Russian Federation in Krasnodar region in 1990 $92,{ }^{18}$ one can understand why more than half of the population of the region prefers Russian-speaking refugees. This must be regarded as a negative reaction to non-Russian migrants who flooded the southern areas of Russia. According to the Ministry of Foreign Affairs, during 1991 the

\begin{tabular}{|lr|}
\hline $\begin{array}{l}\text { Table 10: Respondents in Tambov } \\
\text { Region Not Wishing to Have } \\
\text { Members of Various Groups as } \\
\text { Neighbours (in percent) }\end{array}$ \\
\hline Drug addicts & 87 \\
Homosexuals & 82 \\
Drunkards & 80 \\
People with AIDS & 68 \\
People with a criminal record & 63 \\
Emotionally unbalanced people52 \\
Left-wing extremists & 43 \\
Right-wing extremists & 42 \\
Moslems & 15 \\
People with big families & 12 \\
Immigrants, foreign workers & 11 \\
People of another race & 10 \\
People of a nationality other & \\
than the respondents & 6 \\
\hline
\end{tabular}


number of Meskhetian Turks in Rostov region increased from 6,500 to 9,500 ; in Kabardino-Balkaria, from 160 to 4,000; in Krasnodar, from 7,000 to 12,000 . From June to October 1992 the number of Meskhetian Turks in Voronezh region dropped from 2,784 to 2,368 but the number increased in Krasnodar region from 13,130 to 13,350 . During the same period the number of Armenians grew in Krasnodar region from 14,779 to 14,997 ; in Stavropol region from 14,225 to 15,097 . The number of Azeris increased in Krasnodar region

Table 11: Orientation of NonRussian Refugees in Krasnodar Region to their Current Residence, 1990 and 1992 (in percent)

19901992

Wish to return to their former place of residence or leave for another republic $\quad 35$ 17

Do not wish go elsewhere 65

Table 12: The Most Urgent Problems that Concerned Non-Russian Refugees in Krasnodar Region, 1990 and 1992 (in percent)

\begin{tabular}{|lrr|}
\hline $\begin{array}{l}\text { Problem Type } \\
\text { Residence permit }\end{array}$ & 1990 & 1992 \\
$\quad$ (propiska) & 88 & 83 \\
Employment & 66 & 66 \\
Lodging & 55 & 41 \\
$\begin{array}{l}\text { Compensation for } \\
\text { damages }\end{array}$ & 44 & 42 \\
Language difficulties & 6 & 42 \\
Lack of earnings & 40 & 33 \\
$\begin{array}{l}\text { Children's enrolment in } \\
\text { Daycare and school }\end{array}$ & 42 & 25 \\
$\begin{array}{l}\text { Conflict with } \quad \\
\text { local residents }\end{array}$ & 2 & 25 \\
$\begin{array}{l}\text { Further high school and } \\
\quad \text { College education }\end{array}$ & 29 & 17 \\
$\begin{array}{l}\text { Climate } \\
\text { Religious ceremonies }\end{array}$ & 0 & 8 \\
$\begin{array}{l}\text { Protection of national } \\
\text { Customs and traditions }\end{array}$ & 26 & 0 \\
\hline
\end{tabular}

from 1,269 to 1,337 and in Stavropol region from 1,096 to 1,195.

Refugees in Russia are not always able to choose where they will settle. In Krasnodar region in 1990, 20 percent of non-Russian speaking migrants did not any have choice of where to live. In 1992 , that share grew to 66 percent. The refugees do their best to settle permanently. While in 1990, 65 percent of non-Russian refugees had such intentions, the percentage rose to 83 percent in 1992. Settling permanently was their highest priority (see Tables 11 and 12).

Notwithstanding their losses, 50 percent of non-Russian refugees in Krasnodar region were able to buy their own houses in the early 1990 s. That is largely because relatives and friends of the refugees and migrants who live permanently in the area do their best to help. In 1992, 75 percent of refugees mentioned such assistance, up from 11 percent in 1990 (see Table 13).

The uncontrolled migration and settlement of refugees in the North Caucasus seriously aggravates ethnic relations. The situation regarding the Meskhetian Turks is explosive in the Crimea, Apsheron, Armavir and Koren districts of Krasnodar region. Nearly all refugees experience a feeling of unease and fear for themselves and their relatives regarding possible conflicts with the local people. Onethird of refugees and 62 percent of the local population surveyed mentioned this anxiety in 1990.

Some of the refugees try to escape registration. According to the Ministry of Internal Affairs, in the cities of Stavropol, Georgievsk and Kavkas Mineralni Vodi, many illegal deals have been made with the aim of obtaining apartments against regulations. There are many marriages of convenience and fictitious divorces which allow people to obtain local registration and residence permits (propiska) and thus become eligible for state apartments. Some 1,600 refugees are living in Stavropol region without a propiska.

The adaptation of the migrants has deteriorated because of relations with the local population. The latter view refugees as the cause of the worsening economic and social situation and as rivals in the labour and housing markets. Relations are full of conflict where professionals are involved because competition for administrative positions and material advantages is stiff. The flood of migrants is accompanied by universal rent and price hikes. Half of the respondents in Krasnodar region said that rent and the price of houses and agricultural products have jumped dramatically, and that it had become more difficult to find a good job and a place for children in kindergartens and schools (see Table 14).

According to the State Committee for Ethnic Relations, people of Armenian nationality in Krasnodar region find themselves in the most complicated situation. The Kuban Cossacks openly demonstrate their hostility against the Armenians. The Committee's research shows that the local people have a highly negative attitude toward the refugees because the latter have more money; they do not do manual work but act as traders and brokers. The survey of refugees in the Krasnodar region confirms that refugees obtain money not by earning it in state institutions according to their

Table 13: Refugees' Sources of Income, 1990 and 1992 (in percent)

Means of Existence 19901992

Assistance from relatives or friends $\begin{array}{ll}11 & 75\end{array}$

Part-time work $26 \quad 50$

Compensation

for damage

Work in my speciality at a state enterprise

Work not in my speciality 10

Savings

$60 \quad 25$

Social assistance $40 \quad 0$

Community funds 70

Private assistance 50

Work in cooperatives or small enterprises

Other

$5 \quad 17$ 
occupations but by getting it from relatives and friends in the form of the assistance, from temporary jobs and from "other" sources. Some 92 percent of respondents stressed that they did not have work. Of the refugees who did work, 17 percent were engaged in selling in the markets, 17 percent in commercial ventures, and 50 percent in odd jobs. More than half of the respondents said that TVs, tape recorders, VCRs, furniture, clothes, footwear and cars are available to them.

Ethnic cultural differences play a big role in generating interethnic tensions. Ignorance of, and lack of respect for, local manners and traditions cause local people to become irritated with the newcomers. Thus the image of a refugee that has been created in the minds of the local population does not coincide with the realities of life. Given this background, the places inhabited by refugees are known as criminally dangerous. Information from October 1, 1992 reveals rising annual crime rates in many areas: 41 percent in Krasnodar region, 28 percent in Russia as a whole. The local population readily connects these facts with the arrival of refugees, even though the number of crimes and offences committed by refugees is not large. For example, in

Table 14: Local Population's Opinions about

Changes in Krasnodar Region after the Arrival of Refugees, 1990 and 1992 (in percent)

Conditions of life are the same

Conditions of life are better

Distribution of food and goods has become worse

Price of agricultural products and goods at markets has gone up

It is hard to find a good job

It is more difficult to arrange school and day care for children

65

4

23

The price of houses and apartments has gone up

Inter-ethnic conflicts between people are emerging

Violations of public order have become more frequent 19901992

$35 \quad 13$

$0 \quad 2$

$0 \quad 48$

Stavropol region, twelve crimes were committed by refugees in 1991, and only three during a nine-month period 1992-93 (compared to 142 in Russia

Isolated cases of illegal acts by refugees produce a very sharp reaction on part of the local population, includMineralni vodi, in rural parts of Shapovsky, Novoaleksandrovsk and cause the latter were not working were creating conflict and were said to involved in illegal activities. Such Krasnodar 180,000 ) can be regarded as the most volatile place in the area. Cossacks have confronted the 12,000-14,000 Armenians living there. Hostilities have umed various forms: mutual renians who lacked residence permits, confrontations and attempted executions. In July 1992, two Armenians ere killed.

Recently refugees have begun to be manipulated by destructive elements. For example, in June 1992, a national militant group from South Osetia seized military equipment and weapons under the cover of refugees, including women, elderly people and children. Such incidents cause heightened ethnic tension and further deterioration of the situation.

Research suggests that the local population will not remain a passive witness to the negative consequences of growth in the number of refugees. At the moment, violent methods of dealing with the problem are in general rejected. Thus a 1990 survey found that 14 percent of respondents approved of the violence in Krasnodar region. In 1992 only 9 percent of respondents shared this opinion. Meanwhile the number of people who choose to confront the problem by participating in picketing government offices and institutions has increased from 3 to 13 percent. The percentage of respondents who wish to settle the problem by participating in meetings and demonstrations has also increased from 16 percent to 19 percent. Half of the respondents expressed the wish to join the national-patriotic forces of Russia.

The refugees, however, are more likely to use violent methods to solve their problems. In Krasnodar region in 1992,17 percent of the refugees expressed this willingness while in 1990 not a single refugee did so. A quarter of the respondents said that they had already been involved in conflicts with local people, 58 percent said that they had witnessed such conflicts, 42 percent cited ethnic hatred as the grounds for ethnic conflict, and 64 percent said that ethnic conflict grows out of everyday, routine life (more than one option could be chosen).

Taking all the above into account, one arrives at the following conclusions: The aggravation of the social and criminal situation is caused mainly by the arrival of non-Russian speaking migrants, especially when they settle in the south of Russia. The national and clan traditions of the Caucasian peoples encourage illegal activities and are very dangerous for the refugees in these areas. Another threat involves using refugees in the interests of the clans. On the other hand, the psychological tension of the local population can result in mass confrontations and violence against non-Russian refugees. The danger of forced migration is not so much the number of crimes and offences committed by and against refugees as it is the potential threat of the refugee milieu, which can easily become the source of massive unrest and physical conflict. 